\title{
Application of surface-modified carbon powder in microbial fuel cells
}

\author{
Gaixiu Yang a,b, Yongming Sun ${ }^{b}$, Zhenhong Yuan ${ }^{b}$, Pengmei Lü ${ }^{b}$, Xiaoying Kong ${ }^{b}$, Lianhua Li $^{b}$, \\ Guanyi Chen ${ }^{\mathrm{a}, *}$, Tianhong Lu ${ }^{\mathrm{c}}$ \\ a School of Environmental Science and Technology, State Key Laboratory of Engines, Tianjin University, Tianjin 300072, China \\ b CAS Key Laboratory of Renewable Energy, Guangzhou Institute of Energy Conversion, Chinese Academy of Sciences, Guangzhou 510640, Guangdong, \\ China \\ 'Jiangsu Key Laboratory of Biofunctional Materials, School of Chemistry and Environmental Science, Nanjing Normal University, Nanjing 210097, \\ Jiangsu, China
}

\section{A R T I C L E I N F O}

Article history:

Received 18 October 2013

Accepted 2 January 2014

Published 20 May 2014

\section{Keywords:}

Microbial fuel cell

Oxygen reduction reaction

Carbon powder

Vulcan XC-72R

Surface modification

Electricity generation

\section{A B S T R A C T}

The catalytic activity of surface-modified carbon powder, Vulcan XC-72R (XC), for the oxygen reduction reaction (ORR) at an air cathode in a microbial fuel cell (MFC) has been investigated. The effects of treatment with different chemicals such as nitric acid and ammonia on the chemical characteristics of XC were studied. The catalysts were characterized by Fourier transform infrared spectroscopy (FTIR), Boehm titration, and X-ray photoelectron spectroscopy. FTIR analysis showed that the functional groups of the materials were changed by chemical treatment, with nitric acid causing the introduction of oxygen-containing groups, and ammonia leading to the introduction of nitrogen-containing groups. Electrochemical measurements of MFCs containing various modified carbon materials as ORR catalysts were performed, and the results showed that chemically modified carbon materials are promising catalysts in MFCs.

(C) 2014, Dalian Institute of Chemical Physics, Chinese Academy of Sciences. Published by Elsevier B.V. All rights reserved.

\section{Introduction}

In recent years, microbial fuel cells (MFCs) have attracted much attention as devices that can convert the chemical energy stored in organic or inorganic substrates to electrical energy [1-3]. MFCs could potentially be used in biomass-based energy production. However, the high cost of the materials used in MFCs, particularly the cathode catalyst, has hindered their commercial application. To date, platinum (Pt)-based catalysts have been widely used as cathode catalysts in laboratory-scale MFCs because of their high catalytic activity in the oxygen reduction reaction (ORR). However, Pt-based catalysts are rare and expensive [4]; therefore, development of alternative materials with high catalytic activity in the ORR and sufficient chemical stability is of high priority. Much effort has focused on the development of inexpensive, non-noble metal electrocatalysts to replace Pt-based catalysts. For example, phthalocyanines and porphyrins have been examined as alternatives to $\mathrm{Pt}$ in MFCs [5]. Subsequently, metal oxides such as $\mathrm{MnO}_{2}$ [6] and $\mathrm{PbO}_{2}$ [7] and heterocyclic complexes such as iron (Fe) and cobalt (Co) heterocycles $[8,9]$ have been reported to possess good catalytic activity for the ORR. In addition, manganese phthalocyanine [10], carbon-supported cobalt hydroxide [11], manganese oxides and polypyrrole[12,13] composites prepared by

\footnotetext{
* Corresponding author. Tel: +86-22-87402075; Fax: +86-22-87401929; E-mail: chen@tju.edu.cn

This work was supported by the National Natural Science Foundation of China (21006105) and Opening Project of Key Laboratory of Bioenergy of Henan Province.

DOI: 10.1016/S1872-2067(14)60023-1 | http://www.sciencedirect.com/science/journal/18722067 | Chin. J. Catal., Vol. 35, No. 5, May 2014
} 
electropolymerization have been investigated as potential ORR catalysts. However, these catalysts are unsuitable for practical applications because of the poor electrocatalytic stability of phthalocyanines and transition metal macrocycles, as well as the toxicity of metal dioxides.

Carbon powder has been widely used in fuel cells [14] and could be an inexpensive alternative to noble metal catalysts. The presence of different heteroatoms $(\mathrm{O}, \mathrm{H}, \mathrm{S}$, and $\mathrm{N})$ bonded at the active sites of carbon particles accounts for the surface activity of carbon powder [15]. Recently, Yuan et al. [16] used a polypyrrole/carbon black (Ppy/C) composite as a catalyst for the ORR in an air-cathode MFC. They assumed that the carbon atoms in the $\mathrm{N}$-heterocyclic (pyrrole) ring provided active sites for chemical adsorption of oxygen, which decreased the oxygen activation energy. Their results demonstrated that although the power output with the Ppy/C cathode was lower than that with a commercial Pt cathode, the power per unit cost of the Ppy/C cathode was about 15 times greater than that of the Pt cathode.

Recent studies have shown that surface modification is a useful way to improve catalytic activity. Duteanu et al. [17] found that the electrocatalytic activity of carbon powder treated with nitric acid for the ORR was considerably higher than that of the untreated powder. Moreover, the current density was higher than that of an untreated carbon-supported $\mathrm{Pt}$ cathode. Cheng et al. [18] found that treatment of a carbon cloth anode with ammonia gas substantially increased its surface charge (from 0.38 to $3.99 \mathrm{meq} / \mathrm{m}^{2}$ ), and the combined effects of ammonia treatment of the anode and phosphate treatment of the solution enhanced the power production by $48 \%$ compared with their previous results using an air-cathode MFC. In addition, the start-up time was reduced by $50 \%$. Wang and coworkers [19] investigated the electrocatalytic activity of ammonia-treated ordered mesoporous carbon in the ORR, finding that their modified catalyst exhibited high electrocatalytic performance.

In this study, to further improve the power output and reduce the cost of MFCs, carbon-based Vulcan XC-72R (XC) catalysts were modified by treatment with nitric acid and ammonia. Treatment introduced both oxygen- and nitrogen-containing groups into the XC catalysts. The obtained catalysts were characterized by Fourier transform infrared spectroscopy (FTIR), $\mathrm{X}$-ray photoelectron spectroscopy (XPS), and Boehm titration. The electrocatalytic performance of the XC catalysts for the ORR in MFCs was also tested.

\section{Experimental}

\subsection{Preparation of catalysts}

XC (Cabot, USA) was heated under reflux in 30\% nitric acid for $6 \mathrm{~h}$ at $98^{\circ} \mathrm{C}$. Then, the treated XC was filtered, washed with deionized water, and dried at $60^{\circ} \mathrm{C}$ in a vacuum oven for $12 \mathrm{~h}$. The obtained catalyst is denoted XC-N.

The XC-N catalyst was heated under reflux in 25\% ammonia for $6 \mathrm{~h}$ at $60{ }^{\circ} \mathrm{C}$. The catalyst was then filtered, washed, and dried. The obtained catalyst is denoted XC-NA. Untreated XC is denoted XC-U.
A 20\%-XC-supported Pt catalyst (E-TEK, USA)was used for comparison purposes. It is denoted $\mathrm{Pt} / \mathrm{XC}$.

\subsection{MFC configuration}

An MFC with a single chamber was constructed with $75 \mathrm{~cm}^{3}$ $(5 \mathrm{~cm} \times 5 \mathrm{~cm} \times 3 \mathrm{~cm})$ polymethyl methacrylate, polyacrylonitrile-carbon $(6 \mathrm{~cm} \times 8 \mathrm{~cm} \times 0.5 \mathrm{~cm})$ and graphite felt as the anode catalyst. $20 \% \mathrm{Pt}$ or an XC carbon powder $\left(0.5 \mathrm{mg} / \mathrm{cm}^{2}\right)$ was used as the cathode catalyst. The carbon base layer and cathode catalysts were coated onto the cathode carbon cloth by alternately spraying slurries $\left(2.5 \mathrm{mg} / \mathrm{mL}, \mathrm{V}_{\text {ethanol}}: \mathrm{V}_{\text {nafion}}: \mathrm{V}_{\text {polytetra- }}\right.$ fluoroethylene $=8: 1: 1$ ) and drying at room temperature. Titanium wire was used as the cathode and anode leads. To reduce expense, the proton exchange membrane was replaced by an ion-exchange film purchased from Zhejiang Qianqiu Company, China, and was used to separate the anode and cathode. The acrylic plates, electrodes, and membrane were assembled with a silicon gasket to prevent leakage. A resistor (1000 $\Omega$ ) was routinely used as the load resistor.

\subsection{Enrichment and operation}

The enrichment and adaptation of the electrochemically active bacteria in the MFC were performed in batches; activated sludge was obtained from the Yudai River, Panyu District, Guangzhou (Guangdong, China) for this purpose. Reactors were inoculated with activated sludge $(12.5 \mathrm{~mL})$ and glucose $(1 \mathrm{~g} / \mathrm{L}$, $62.5 \mathrm{~mL}$ ) culture media solution. The culture media solution contained $\mathrm{KH}_{2} \mathrm{PO}_{4}(13.6 \mathrm{~g} / \mathrm{L}), \mathrm{NaOH}(2.32 \mathrm{~g} / \mathrm{L}), \mathrm{NH}_{4} \mathrm{Cl}(0.31$ $\mathrm{g} / \mathrm{L}), \mathrm{NaCl}(1.0 \mathrm{~g} / \mathrm{L})$, and a mineral stock solution $(12.5 \mathrm{~mL} / \mathrm{L})$ [20].

The single-chamber MFCs were operated at ambient temperature. Each experiment was performed in duplicate.

\subsection{Analysis and calculation}

The external circuit voltages $(E)$ of the MFCs were measured by a data acquisition card (model ZP1001) from Guangzhou NXP Ltd, China. The power density $(P)$ was measured by varying the external resistance in the MFC circuit from 30 to 80000 $\Omega$. Parameters of the MFC were calculated using the formulae: $j$ $=E / R A, P=E^{2} / R V$ and $E=U-I r$, where $U$ is the electromotive force $(\mathrm{V}), r$ is the battery internal resistance $(\Omega), R$ is the external resistance $(\Omega), A$ is the apparent area of the anode catalyst $\left(\mathrm{cm}^{2}\right), V$ is the volume of the anode chamber, and $I$ is the current (A). FTIR spectra of the carbon supports were collected on an infrared spectrometer (Tensor 27, Brooke, Germany). For XPS measurements, a high-resolution Kratos AXis Ultra (DLD) $\mathrm{X}$-ray photoelectron spectrometer with an $\mathrm{Al}\left(K_{\alpha}\right)$ radiation probe was used.

\subsection{Electrochemical measurements}

To investigate the ORR activity of the different catalysts, linear sweep voltammetry (LSV) was performed with a rotating disk electrode (RDE, Pine Instruments, USA). A Pt wire and 
saturated calomel electrode were used as the counter and reference electrode, respectively. Catalyst-coated glassy carbon (5.0-mm diameter) electrodes were used as the working electrodes. All electrochemical measurements were conducted with $50 \mathrm{mmol} / \mathrm{L}$ phosphate buffered saline (PBS) as an electrolyte.

\section{Results and discussion}

\subsection{Effects of surface modification of the materials}

FTIR spectra of the cathode materials are shown in Fig. 1. The intensity of the bands at 1750-1680 and 3600-3300 $\mathrm{cm}^{-1}$, corresponding to oxygen-containing groups [21], increased markedly after treatment with nitric acid (Fig. 1(2)). According to the literature [21,22], oxygen-containing groups exist mainly in the form of carboxyl groups. Nitric acid treatment made the surface of the carbon material rich in both weakly and strongly acidic groups [22]. Therefore, when the XC-N catalyst was further treated with ammonia, hydrogen bonds formed between the acid groups on the XC surface and ammonia. Peak splitting was found in the bands at 1750-1680 and 3600-3300 $\mathrm{cm}^{-1}$ following treatment with ammonia (Fig. 1(1)). This is mainly attributed to the stretching vibration of $\mathrm{N}-\mathrm{H}$ [23].

It is well known that oxygen-containing functional groups can enhance the ion-exchange capability of carbon. The total surface acidity and basicity of cathodic materials can be quantitatively measured by Boehm titration [24,25]. This classical method is the most popular approach for the chemical analysis (both qualitative and quantitative) of carbon surfaces. Figure 2 reveals that the nitric acid-treated carbon (XC-N) has the highest total surface acidity of the cathodes of $0.75 \mathrm{mmol} \mathrm{L}^{-1} \mathrm{~g}^{-1}$; this sample also shows the lowest total surface basicity of $\sim 0.12 \mathrm{mmol} \mathrm{L}^{-1} \mathrm{~g}^{-1}$. The total surface basicity of the XC-NA catalyst rose to $0.43 \mathrm{mmol} \mathrm{L}^{-1} \mathrm{~g}^{-1}$, which is comparable to its surface acidity. This confirms that treatment with nitric acid can introduce oxygen-containing groups onto the surface of carbon, and that ammonia treatment can introduce nitrogen-containing groups [26]. This result is in accordance with those of FTIR analysis.

The carbon (C), nitrogen (N), and oxygen (O) contents of the different carbon materials used in this work were analyzed by XPS (Table 1). Combined treatment with nitric acid and ammonia increased the $\mathrm{O}$ and $\mathrm{N}$ contents from $1.05 \%$ and 0 to

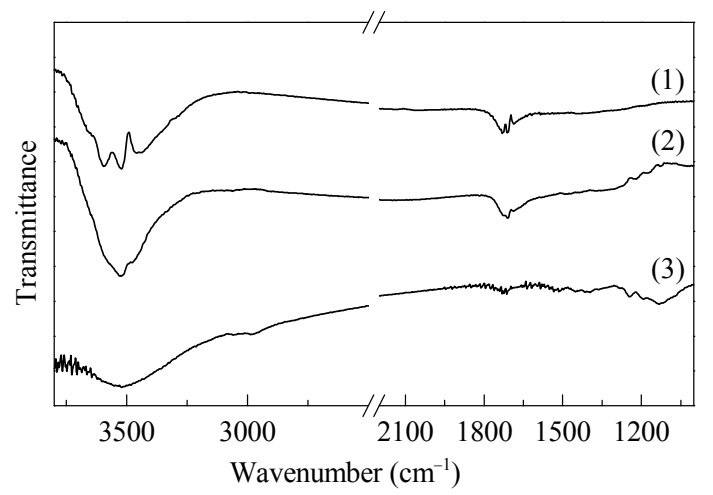

Fig. 1. FTIR spectra of XC-NA (1), XC-N (2), and XC-U (3) catalysts.

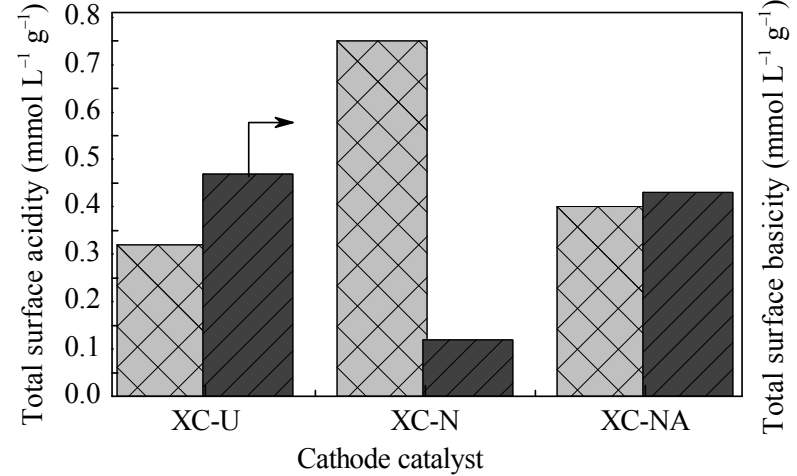

Fig. 2. Total surface acidity and basicity of XCs determined by Boehm titration.

Table 1

Elemental composition of the XC-U, XC-N, and XC-NA catalysts obtained from XPS.

\begin{tabular}{lccc}
\hline \multirow{2}{*}{ Sample } & \multicolumn{3}{c}{ Element atomic fraction (\%) } \\
\cline { 2 - 4 } & $\mathrm{C}$ & $\mathrm{N}$ & 0 \\
\hline XC-U & 98.95 & 0.0 & 1.05 \\
XC-N & 96.94 & 0.25 & 3.06 \\
XC-NA & 85.03 & 0.92 & 14.05 \\
\hline
\end{tabular}

$14.05 \%$ and $0.92 \%$, respectively. This observation further confirms that treatment with nitric acid leads to the introduction of oxygen-containing function groups, and thus an increase of the oxygen (carboxylic acid group) content on the carbon surface. This increase in the superficial oxygen content is correlated with increased catalytic activity for the ORR [16,27].

Further differentiation between the types of all surface groups was obtained using XPS analysis, as shown in Fig. 3. The treatment method changed the number and kind of surface species. The XPS O $1 s$ spectra of the XC-NA catalyst (Fig. 3(a)) contain peaks at around 531, 532-534, and $535 \mathrm{eV}$ derived from $\mathrm{C}=0$, quinone-type (0-1), and $\mathrm{C}-\mathrm{OH}$ phenol groups and/or $\mathrm{C}-\mathrm{O}-\mathrm{C}$ ether groups (0-2) and chemisorbed oxygen $\mathrm{COOH}$ carboxylic groups) and/or water (0-3) [28]. Nitric acid treatment resulted in an increase of surface acidity because of an increase in the number of $\mathrm{C}=0$ species [29]. These are attributed to $\mathrm{C}=0$ of carboxylic groups, which are responsible for an increase in surface acidity, as demonstrated by wet titration data. Fig. 3(d) shows the N 1s spectra of the XC-NA catalyst, with binding energies located at 398.8 and $400 \mathrm{eV}$ consistent with the pyridinic (N-6) and pyrrolic/pyridone (N-5) or nitrile groups, respectively. This further confirms that treatment with ammonia introduced nitrogen-containing groups onto the catalyst. It appears that ammonia treatment favored the formation of pyridinic (N-6) and pyrrolic/pyridone (N-5) groups [30]. No signal for $\mathrm{N}$ was detected from the XC-U catalyst, so the content of surface nitrogen in the catalyst was below the detection limit.

\subsection{Performance of the MFCs with different cathodes}

Figure 4 shows the relationship between voltage output and reaction time for the single-chamber MFCs equipped with XC-NA, XC-N, XC-U, and Pt/XC air-cathodes, respectively. The 

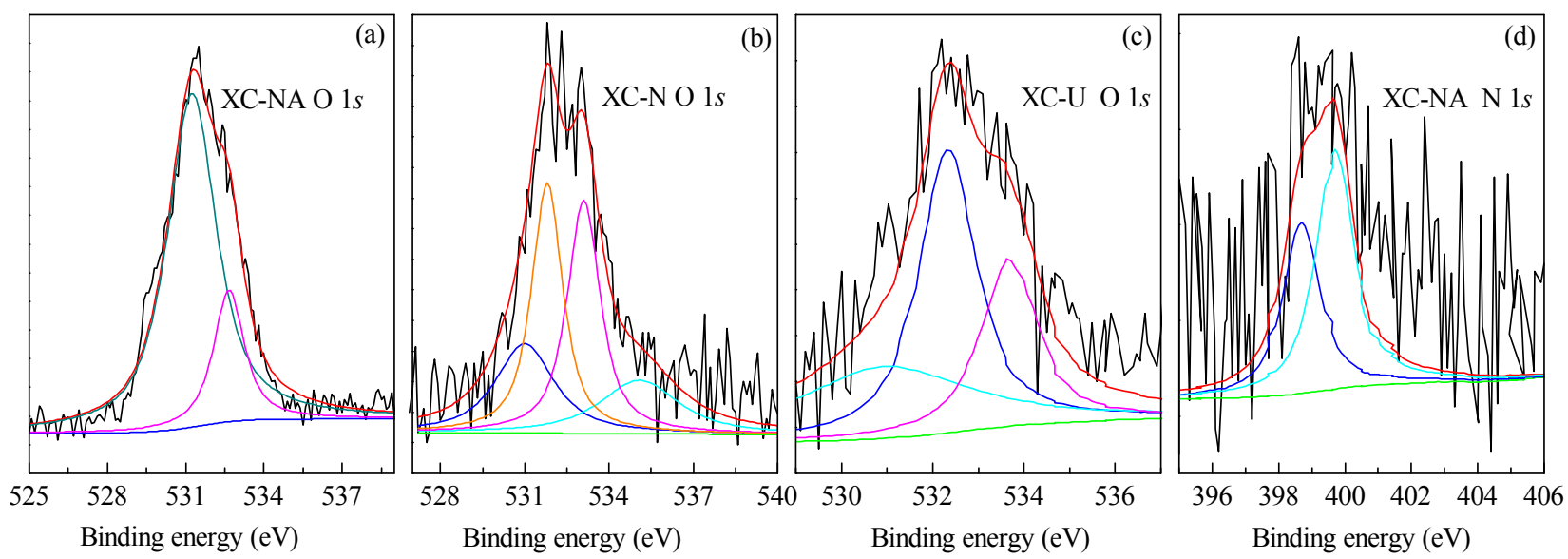

Fig. 3. XPS O $1 s$ spectra of XC-NA (a), XC-N (b), XC-U (c) and N $1 s$ spectra of XC-NA (d).

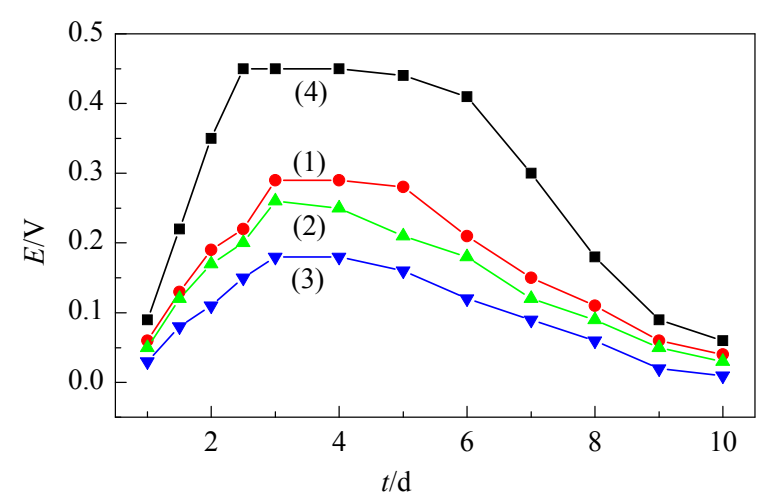

Fig. 4. Relationship between voltage output and reaction time of different cathodes. (1) XC-NA; (2) XC-N; (3) XC-U; (4) Pt/XC.

stable voltage outputs of the MFCs with different cathodes were in the descending order Pt/XC $>$ XC-NA $>$ XC-N $>$ XC-U. The fastest reaction time was demonstrated by the $\mathrm{Pt} / \mathrm{XC}$ cathode (Fig. 4(4)). The catalyst treated with nitric acid and ammonia exhibited the second-best performance. The XC-U cathode had the lowest performance of the carbon cathodes. These results demonstrate that surface modification of XC improves not only the electrocatalytic activity but also the stability of the catalyst.

To further demonstrate the electrocatalytic capability of these catalysts for the ORR, their power output was examined in terms of the maximum power density (Fig. 5) and open-circuit voltage (OCV) of the MFCs (Table 2). The maximum power density was obtained from the MFC with the XC-NA cathode $\left(1788 \mathrm{~mW} / \mathrm{m}^{3}\right)$. This value is lower than that obtained with $\mathrm{Pt} / \mathrm{XC}\left(2525 \mathrm{~mW} / \mathrm{m}^{3}\right)$ and higher than that from the MFCs with XC-N and XC-U cathodes (1560 and $501 \mathrm{~mW} / \mathrm{m}^{3}$, respectively). The internal resistance of the MFCs with different cathode catalysts decreased in the order XC-U $>$ XC-N $>$ XC-NA $>$ Pt/XC. This indicates that surface modification can decrease the internal resistance of the MFC although the resistance is still higher than that of the MFC with the Pt/C catalyst. It is well known that OCV is an important indicator for MFCs because it shows its capacity for electricity generation.
The OCV values of the MFCs with different cathodes exhibited the order Pt/XC $>$ XC-NA $>$ XC-N $>$ XC-U (Table 2). The superior electrocatalytic performance observed for XC-NA compared with the other carbon cathodes can be attributed to the incorporation of both oxygen- and nitrogen-containing groups into the XC structure increasing the content of electrocatalytically active groups. This result strongly suggests that XC-NA contributes to the power increase because of its catalytic activity for the ORR. Notably, the electrocatalytic performance of the XC-NA catalyst was only slightly improved compared with that of the XC-N catalyst. Thus, $\mathrm{C}=0$ groups may contribute more to the activity of the catalysts in the ORR than the $\mathrm{N}$ groups.

\subsection{Catalytic activity of the catalysts in the ORR}

In catalytic chemistry, treatment of carbon catalysts can markedly influence their performance. We used an RDE to study the ORR activity of the catalysts treated by different

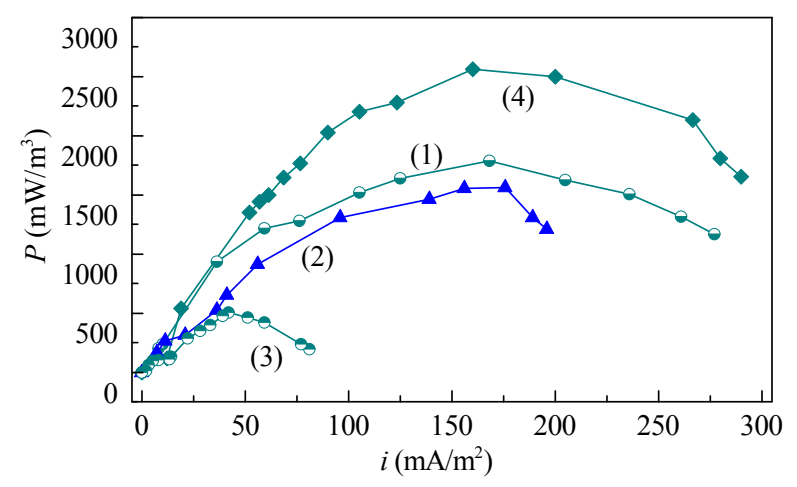

Fig. 5. Power density versus current density curves for different cathodes. (1) XC-NA; (2) XC-N; (3) XC-U; (4) Pt/XC.

Table 2

OCV of MFCs with different cathodes.

\begin{tabular}{lcc}
\hline Sample & Processing method & OCV (V) \\
\hline XC-U & Untreated & 0.26 \\
XC-N & Nitric acid & 0.52 \\
XC-NA & Nitric acid-ammonia & 0.60 \\
Pt/XC & Untreated & 0.68 \\
\hline
\end{tabular}




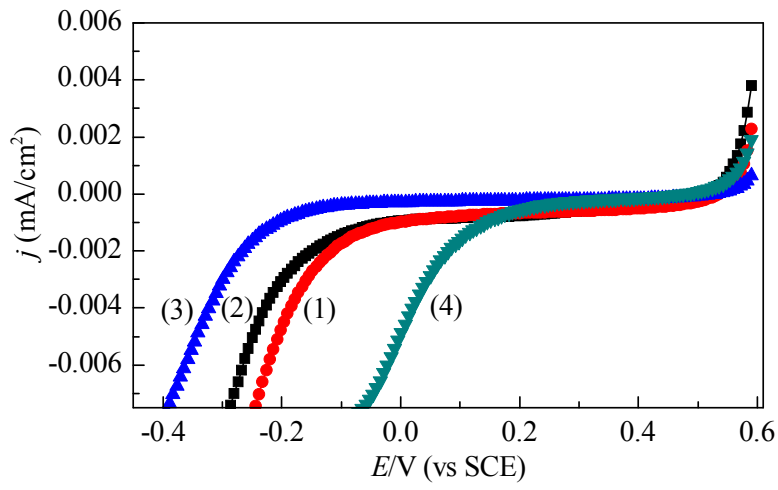

Fig. 6. LSVs of XC-NA (1), XC-N (2), XC-U (3) and Pt/XC (4) catalysts for the ORR at a scan rate of $10 \mathrm{mV} / \mathrm{s}$ in $50 \mathrm{mmol} / \mathrm{L}$ PBS.

methods. Figure 6 shows the LSVs of different catalysts for the ORR at a scan rate of $10 \mathrm{mV} / \mathrm{s}$ in $50 \mathrm{mmol} / \mathrm{L}$ PBS. The onset potentials of the ORR on different catalysts exhibited the order $\mathrm{Pt} / \mathrm{XC}>\mathrm{XC}-\mathrm{NA}>\mathrm{XC}-\mathrm{N}>\mathrm{XC}-\mathrm{U}$. The Pt/XC catalyst showed the highest catalytic activity in the ORR of the catalysts investigated. Notably, surface treatment improved the catalytic activity of $\mathrm{XC}$ in the ORR. This could be related to the introduction of oxygen and nitrogen radicals supplying more active sites for oxygen chemical adsorption, which could weaken the 0-0 bond and lower the activation energy for reduction. Even though the XC-NA catalyst is less active than the Pt/C catalyst, it is more cost effective, which is an important advantage.

\section{Conclusions}

The aim of this study was to reduce the cost of the cathode in MFCs and improve its performance. We found that chemical treatment with nitric acid and ammonia modifies the surface and improves the electrocatalytic performance of carbon powder. Electrochemical analysis revealed that the XC-NA cathode catalyst exhibited the highest catalytic performance in the ORR $\left(1788 \mathrm{~mW} / \mathrm{m}^{3}\right)$ of the investigated catalysts, following the reference Pt/XC catalyst. Such a chemically modified carbon material can act as a cheaper alternative to the Pt-based catalysts currently used in MFC cathode construction.

\section{References}

[1] Lefebvre 0, Tan Z, Shen Y, Ng H Y. Bioresource Technol, 2013, 127: 158

[2] Ieropoulos I, Galvez A, Greenman J. Enzyme Microbial Technol, 2013, 52: 32

[3] Futamata H, Bretschger O, Cheung A, Kan J, Owen R, Nealson K H. J Biosci Bioeng, 2013, 115: 58

[4] Yang S Q, Jia B Y, Liu H. Bioresource Technol, 2009, 100: 1197

[5] Yu E H, Cheng S, Logan B E, Scott K. J Appl Electrochem, 2009, 39: 705

[6] Li X, Hu B, Suib S, Lei Y, Li B. J Power Sources, 2010, 195: 2586

[7] Morris J M, Jin S, Wang J, Zhu C, Urynowicz M A. Electrochem Commun, 2007, 9: 1730

[8] Bashyam R, Zelenay P. Nature, 2006, 443: 63

[9] Zhu K N, Qin H Y, Liu B H, Li Z P. J Power Sources, 2011, 196: 182

[10] Rodrigues N P, Obirai J, Nyokong T, Bedioui F. Electroanalysis, 2005, 17: 186

[11] Qin H Y, Liu Z X, Ye L Q, Zhu J K and Li Z P. J Power Sources, 2009, 192: 385

[12] Ding K Q, Cheng F M. Synth Metals, 2009, 159: 2122

[13] Nguyen Cong H, El Abbassi K, Gautier J, Chartier P. Electrochim Acta, 2005, 50: 1369

[14] Sui S, Zhuo X L, Su K H, Yao X Y, Zhang J L, Du S F, Kendal K. J Energy Chem, 2013, 22: 477

[15] Harnisch F, Wirth S, Schröder U. Electrochem Commun, 2009, 11: 2253

[16] Yuan Y, Zhou S G, Zhuang L. J Power Sources, 2010, 195: 3490

[17] Duteanu N, Erable B, Senthil Kumar S M, Ghangrekar M M, Scott K. Bioresource Technol, 2010, 101: 5250

[18] Cheng S A, Logan B. Electrochem Commun, 2007, 9: 492

[19] Wang Q, Huang L P, Yu H T, Quan X, Chen G H. Acta Phys-Chim Sin, 2013, 29: 889

[20] Watson V J, Nieto Delgado C, Logan B. Environ Sci Technol, 2013, 47: 6704

[21] Figueiredo J L, Pereira M F R, Freitas M A, Orfao J M. Carbon, 1999, 37: 1379

[22] Chen W M, Xin Q, Sun G Q, Wang Q, Mao Q, Su H D. J Power Sources, 2008, 180: 199

[23] Le Leuch L M, Bandosz T J. Carbon, 2007, 45: 568

[24] Yuan Y, Zhou S G, Tang J H. Environ Sci Technol, 2013, 47: 4911

[25] Boehm H P, Diehl E, Heck W, Sappok R. Angew Chem Int Ed, 1964, 3: 669

[26] Mansoorian H J, Mahvi A H, Jafari A J, Amin M M, Rajabizadeh A,

\section{Graphical Abstract}

\section{Chin. J. Catal., 2014, 35: 770-775 doi: 10.1016/S1872-2067(14)60023-1}

\section{Application of surface-modified carbon powder in microbial fuel cells}

Gaixiu Yang, Yongming Sun, Zhenhong Yuan*, Pengmei Lü, Xiaoying Kong, Lianhua Li, Guanyi Chen, Tianhong Lu

Guangzhou Institute of Energy Conversion, Chinese Academy of Sciences;

Tianjin University; Nanjing Normal University

The introduction of nitrogen- and oxygen-containing surface functional groups onto carbon catalysts improved their catalytic activity toward the oxygen reduction reaction in microbial fuel cells.

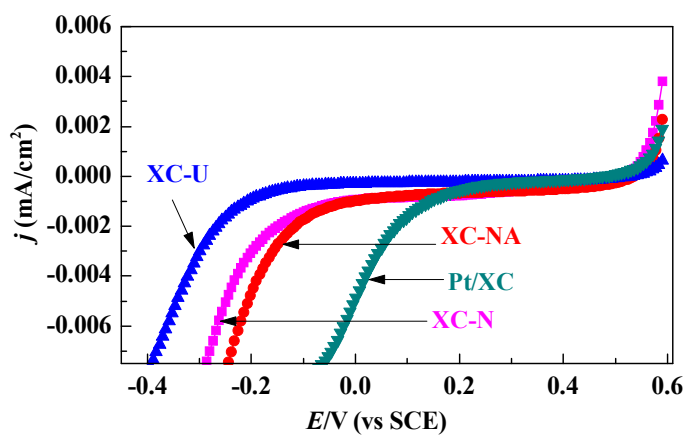


Khanjani N. Enzyme Microb Technol, 2013,52: 352

[27] Tricas N, Borros S. Kgk-Kautschuk Gummi Kunststoffe, 2005, 58 511

[28] Kinoshita H, Nakayama T, Matsumoto N, Ohmae N. Carbon, 2011,
49: 3388

[29] Plomp A J, Su D S, de Jong K P, Bitter J H. J Phys Chem C, 2009, 113 9865

[30] Jansen R J J, Bekkum H. Carbon, 1995, 33: 1021

\title{
表面改性炭材料在微生物燃料电池中的应用
}

\author{
杨改秀 ${ }^{\mathrm{a}, \mathrm{b}}$ ，孙永明 ${ }^{\mathrm{b}}$ ，袁振宏 ${ }^{\mathrm{b}}$ ，吕鹏梅 ${ }^{\mathrm{b}}$ ，孔晓英 ${ }^{\mathrm{b}}$ ，李连华 ${ }^{\mathrm{b}}$ ，陈冠益 ${ }^{\mathrm{a},{ }^{*}}$ ，陆天虹 ${ }^{\mathrm{c}}$ \\ a天津大学环境科学与工程学院, 内燃机燃烧学国家重点实验室, 天津 300072 \\ $\mathrm{b}$ 中国科学院广州能源研究所, 中国科学院可再生能源重点实验室, 广东广州510640 \\ $\mathrm{c}$ 南京师范大学化学与材料科学学院, 江苏省生物功能材料重点实验室, 江苏南京210097
}

摘要: 研究了在空气阴极微生物燃料电池中修饰方法如硝酸处理和硝酸-氨水酸碱等对XC-72R作为阴极氧还原催化剂催化活性 的影响, 并且使用傅里叶变换红外光谱(FTIR)、Boehm滴定法和X射线光电子能谱(谱(XPS)等手段对催化剂进行了表征. FTIR测 试证明硝酸处理可引入含氧基团氨水处理可引入含氮基团. 另外, 还测试了含有不同表面官能团的XC-72R对氧还原的活性, 并 将其作为阴极催化剂用在MFC中, 测试了电池性能. 实验表明, 经酸碱修饰的XC-72R 作为空气阴极MFC的催化剂具有很好的应 用前景.

关键词：微生物燃料电池; 氧还原反应; 碳粉; Vulcan XC-72R碳黑; 表面改性; 产电性能

收稿日期: 2013-10-18. 接受日期: 2014-01-02. 出版日期: 2014-05-20.

*通讯联系人. 电话: (022)87402075; 传真: (022)87401929; 电子信箱: chen@tju.edu.cn

基金来源：国家自然科学基金(21006105); 河南省生物质能重点实验室开放基金.

本文的英文电子版由Elsevier出版社在ScienceDirect上出版(http://www.sciencedirect.com/science/journal/18722067). 